\title{
CROSS APPLICATION OF ENTOMOPATHOGENIC FUNGI RAW SECONDARY METABOLITES FOR CONTROLLING FUSARIUM WILT OF CHILI SEEDLINGS
}

\author{
Loekas Soesanto, Lintang Yunita Sari, Endang Mugiastuti, \& Abdul Manan \\ Faculty of Agriculture, Jenderal Soedirman University, Indonesia \\ Jl. Dr. Soeparno 73 Purwokerto 53122 \\ E-mail: lukassusanto26@gmail.com
}

Manuscript received: 29 January 2021. Revision accepted: 15 March 2021.

\begin{abstract}
Cross application of entomopathogenic fungi raw secondary metabolites for controlling fusarium wilt of chili seedlings. The research aimed to determine the effect of entomopathogenic fungi raw secondary metabolites on fusarium wilt on chili plants and on growth of chili. In vitro test used a Completely Randomized Design with 5 treatments and 5 replicate and in planta using a Randomized Block Design with 5 treatments and 5 replicatie including control, secondary metabolites of Beauveria bassiana B10, B. bassiana B16, Metarhizium anisopliae M16, dan Lecanicillium lecanii L16. Variables observed included inhibition ability, incubation period, desease intensity, plant height, root length, and phenolic compounds (tannins, saponin, and hydroquinone) content qualitatively. The results showed that secondary metabolites of $B$. bassiana $\mathrm{B} 10$, B. bassiana $\mathrm{B} 16$, M. anisopliae M16, and L. lecanii L16 were able to inhibit growth of Fusarium oxysporum f.sp. capsici by $50.62 ; 50,64 ; 48,62 ; 56.62 \%$, respectively, extend incubation periods of $71.05 ; 73,38 ; 64.89$; and $68.57 \%$, respectively, suppress disease intensity by $99.99 ; 99.99 ; 99.99$; and $99.99 \%$, respectively, can increase plant height by $15.22 ; 18.8 ; 21.14 ; 21.69 \%$, respectively, increasing the root length by $22.61 ; 25,71 ; 26,34 ; 33.50 \%$, respectively, and can increase the content of tannins, saponins and hydroquinone compounds qualitatively compared to controls. The secondary metabolites of enthomopathogenic fungi could be used as organic control for soilborne pathogenic fungi.
\end{abstract}

Key words: chili plants, fusarium wilt, entomopathogenic fungi, secondary metabolites

\section{INTRODUCTION}

Chili pepper (Capsicum annum L.) was an important horticultural crops in the tropics and subtropics (Baenas et al., 2018; Olatunji \& Afolayan, 2018). Cultivation of chili crops was inseparable from pest disturbances. One of the disorders that occur in chili crops was wilt disease caused by Fusarium oxysporum f.sp. capsici (Gabrekiristos \& Demiyo, 2020). F. oxysporum f.sp. capsici caused a high loss of chili production (VelardeFélix et al., 2018; Gabrekiristos \& Demiyo, 2020) and was able to survive in the soil for a long time as chlamydospores even though there were no host (Gordon, 2017; Altinok et al., 2019). Transmission could occur through soil and planting material derived from diseased plants and could infect host plants through wounds on the roots (VelardeFélix et al., 2018).

So far, fusarium wilt control still depended on fungicides (Bashir et al., 2018). However, with the increasing awareness of consumers and the negative impacts of fungicide, including the emergence of a new fungicide-resistant strain of Fusarium, it was necessary to use other alternative controls that were environmentally friendly and safe (Besset-Manzoni et al., 2019). One of the controls that could be carried out to control fusarium wilt in chili plants was by using biological agents.

Several biological agents have been tried, but the results was fluctuate, this due to $F$. oxysporum as a soilborne fungus that difficult to control (Köhl et al., 2019). Entomopathogenic fungi were biological agents that have been used to control insect pests and were generally sporebased (Mora et al., 2017; Litwin et al., 2020). The application of spore-based biological agents in the field encountered several obstacles, including (a) stress of abiotic factors, such as temperature, humidity, and sunlight which would affect conidium germination and spore production (Hsia et al., 2014; Velivelli et al., 2014), (b) propagation medium, had an effect on the stability of conidium and blastopore production, reduced sources of protein, carbon, starch, and chitin in the propagation medium could decrease the quality of the entomopathogenic fungi spores, so that it needed to be overcome by using secondary metabolites (Roshandel et al., 2016; Corrêa et al., 2020).

Secondary metabolites are inherent genetic properties of an organism. Several entomopathogenic fungi are known to produce secondary metabolites that were 
biologically active (Fernandes et al., 2012; Kim et al., 2013; Gustianingtyas et al., 2020). Secondary metabolites of entomopathogenic fungi contain various compounds, especially the chitinase (Fernandes et al., 2012; de Laguna et al., 2015; Altinok et al., 2019), which degrade chitin, and which also make up the conidium layer of pathogenic fungi. Beauveria bassiana had shown antifungal activity against $F$. oxysporum, $F$. oxysporum f.sp. cepae, F. oxysporum f.sp. lycopersici, Armillaria mellea, Rosellinia necatrix, Botrytis cinerea, Pythium ultimum, $P$. debaryanum, P. myriotylum, Septoria nodorum, and Rhizoctonia solani (Ownley et al., 2010). According to Jaber \& Ownley (2018), the possible mechanisms of protection conferred by endophytic fungal entomopathogens were as dual microbial control agents against both insect and pathogen pests. Based on these secondary metabolites, it is necessary to try cross-application of the secondary metabolites of entomopathogenic fungi to plant diseases. This study aimed to determine the effect of entomopathogenic fungi secondary metabolites on fusarium wilt disease in chili plants and on the growth of chili plants.

\section{MATERIALS AND METHODS}

Research Site. The research was carried out in the screen house for 4 months and the preparation was done in the Laboratory of Plant Protection, Faculty of Agriculture, Jenderal Soedirman University, Purwokerto.

Preparation of Enthomopatogenic Fungi. Each of the entomopathogenic fungi $B$. bassiana $\mathrm{B} 10, B$. bassiana B16, Metarhizium anisopliae M16, and Lecanicillium lecanii L16 (Loekas Soesanto collection) were purified on Potato Dextrose Agar (PDA) media (Fitriana et al., 2018). Each culture was incubated at room temperature for 7 days.

Preparation of $\boldsymbol{F}$ oxysporum f.sp. capsici. Preparation of the plant pathogenic fungi $F$. oxysporum f.sp. capsici was performed by isolating chili plants with the symptom of fusarium wilt. Isolation was carried out by cutting the base of the infected chili plant, then sterilized with $70 \%$ alcohol by soaking for $1 \mathrm{~min}$, after that rinsed with distilled water for $1 \mathrm{~min}$. Furthermore, grown on PDA media and incubated at room temperature for 5 days (Kalman et al., 2020).

Preparation of Secondary Metabolites. As much as $20 \mathrm{~g}$ of rice flour and $10 \mathrm{~g}$ of granulated sugar were boiled with $1000 \mathrm{~mL}$ of water, then put into 10 glass bottles (100 $\mathrm{mL}, \mathrm{v} / \mathrm{v})$. The mixture was sterilized using an autoclave at a temperature of $121^{\circ} \mathrm{C}$, a pressure of 15 psi for $30 \mathrm{~min}$. After the mixture was cooled, each pure culture of B. bassiana B10, B. bassiana B16, M. anisopliae M16, and $L$. lecanii L16, was taken from the PDA medium with a cork drill (10 mm in diameter) and each of 5 cork drills was put into the mixture and shaken with a shaker at $150 \mathrm{rpm}$ at room temperature for 10 days (Soesanto et al., 2019).

Preparation of Chili Seedlings. Chili seeds were soaked for 1 hours according to treatment. The seeds were spread on a box $(20 \times 30 \times 8 \mathrm{~cm})$ filled with fine soils for 3 weeks then replanted in polybags according to the treatment. The planting medium used was unsterlized soil mixed with manure in a ratio of $2: 1$, then put in a $40 \times 40 \mathrm{~cm}$ polybag.

In vitro Antagonism Test. In vitro antagonism tests were carried out between secondary metabolites of B. bassiana $\mathrm{B} 10$, B. bassiana $\mathrm{B} 16$, M. anisopliae M16, and L. lecanii L16, and the phytopathogenic fungi F. oxysporum f.sp. capsici. The 7 days old culture of phytopathogenic fungi was taken using a cork drill ( $9 \mathrm{~mm}$ in diameter) then transferred to the new PDA in a petri dish using a spatula aseptically at a distance of $3 \mathrm{~cm}$ from the edge of the Petri dish. A Sterile filter paper ( $5 \mathrm{~mm}$ in diameter) was dipped in each of the entomopathogenic fungi secondary metabolites then placed aseptically to the same petri dish with a distance of $3 \mathrm{~cm}$ from the fungus (Živkovic et al., 2010). The cultures then incubated at room temperature using a completely randomized design (CRD) with 5 treatments and 5 repeatation.

Application of Chili Seedlings. Planting holes were made for polybags containing planting medium, then inoculated the fungus $F$. oxysporum f.sp. capsici into the planting hole as many as 5 cork drill molds. After 5 days of transplanting, the secondary metabolites of B. bassiana $\mathrm{B} 10$, B. bassiana $\mathrm{B} 16$, M. anisopliae M16, and L. lecanii L16 were poured each of $50 \mathrm{~mL} /$ plant and repeated with the same volume of watering 10 days after transplanting. On the $15^{\text {th }}$ and $20^{\text {th }}$ days after transplanting the plants were watered with $100 \mathrm{~mL} /$ plant of entomopathogenic fungal secondary metabolites. The test used a randomized block design with 5 treatments repeated 5 times.

Inhibition Ability Test. Pathogen growth was measured and data on the inhibition of mycelia growth was calculated using a formula (Bekker et al., 2006):

$$
\mathrm{P}=\left(\frac{\mathrm{r}_{2}-\mathrm{r}_{1}}{\mathrm{r}_{2}}\right) \times 100 \%
$$


$\mathrm{P}=$ percentage of inhibition (\%);

$\mathrm{r}_{1}=$ colony radius of $F$. oxysporum f.sp. capsici facing the fungal colony;

$r_{2}=$ radius facing the edge of the Petri dish

Incubation Period. The incubation period was calculated from the first day of inoculation of the pathogen until the first symptoms of disease appear in plants, with units of days after inoculation.

Disease Intensity. Disease intensity observations were carried out every week, since the first symptoms appeared, using the following formula (Abdel-Monaim \& Ismail, 2010):

$$
\mathrm{DI}=\frac{\sum(\mathrm{v} \times \mathrm{n})}{\mathrm{Z} \times \mathrm{N}} \times 100 \%
$$

DI = disease intensity (\%);

$\mathrm{V}=$ infection category score;

$\mathrm{N}=$ number of plants attacked in each category;

$\mathrm{Z}=$ the hightes attack category score;

$\mathrm{N}=$ number of plants observed, with attack category: $0=$ healthy $\%$ plants, $1=$ wilted plants $1-20 \%$; starting at the lower leaves and the base of the brown stems; $2=21-40 \%$ wilted plants, brownish rot at the base of the stems; $3=41-60 \%$ wilted plants, rotting the base of the stem is expanding but still on the surface of the soil; $4=$ the plant is wilted $61-80 \%$, the rot of the base of the stem is more than $5 \mathrm{~cm}$ and has reached the bottom; $8=$ the plants is wilted $>81 \%$ and has reached the generative part.

Qualitative Content of Tannin, Saponin, and Hydroquinone Compounds. The phenol compound analysis was carried out at the end of the study qualitatively on the chili plant tissue. Tests carried out based on Rahmania et al. (2018) include tannin and saponin. Tannin, saponin, and hydroquinone tests were carried out by extracting $10 \mathrm{~g}$ of plant material with $80 \%$ ethanol then filtered and added $10 \mathrm{~mL}$ of distilled water. A total of $5 \mathrm{~mL}$ of plant extract was then put into a test tube. Three drops of $\mathrm{FeCl}_{3}$ then added to the extract. Hydrolyzed tannins gave a blackish blue color, while tannin condensation gave a blue green color, then compared to the control (Bele et al., 2010). Saponin test was carried out by taking 1 drop of lerak and then adding $10 \mathrm{~mL}$ of water (as a control) to the test tube. The filtered extract was put into a 5-10 mL test tube, then shaken vigorously for $30 \mathrm{sec}$ and let stand for $30 \mathrm{~min}$. The foam that was formed more than $3 \mathrm{~cm}$ from the surface of the solution means that it was positive for saponins. If the foam is formed a little, then add a little $\mathrm{Na}_{2} \mathrm{CO}_{3}$ solution (Ribeiro et al., 2013). The foam condition that remains stable and hard indicates the presence of free fatty acids (Vidal et al., 2018). The hydroquinone test was carried out based on Gull et al. (2016), which is modified. A total of $5 \mathrm{~mL}$ of extracted results added 5 drops of $10 \%$ $\mathrm{NaOH}$. The red color indicates hydroquinone.

Growth Components. Variable of pepper seedlings growth components was crop height and root length.

Data Analysis. Data diversity was analyzed using the $F$ test with an error rate of $5 \%$. If significantly different, the HSD (Honest Significantly Difference) was carried out at an error level of $5 \%$.

\section{RESULTS AND DISCUSSION}

Inhibition Ability Test. The growth of $F$. oxysporum f.sp. capsici was inhibited by secondary metabolites of B. bassiana B10, B. bassiana B16, M. anisopliae M16, and $L$. lecanii L16, respectively $50.62 ; 50.64 ; 48.62$; and $56.62 \%$ compared to control (Table 1). This was presumably because in the entomopathogenic fungi secondary metabolites tested contained compounds that were detrimental to the fungus $F$. oxysporum f.sp. capsici so that the growth of the pathogenic fungi is inhibited. This was in accordance with Gustianingtyas et al. (2020) that the compounds contained in the secondary metabolites of entomopathogenic fungi were in the form of extracellular

Tabel 1. Inhibition of growth of F. oxysporum f.sp. capsici by secondary metabolites of four entomopathogenic fungi on the $5^{\text {th }}$ day of testing

\begin{tabular}{lc}
\hline Treatments & Growth inhibition (\%) \\
\hline Control & 0 a \\
SM of B. bassiana B10 & $50.62 \mathrm{~b}$ \\
SM of B. bassiana B16 & $50.64 \mathrm{~b}$ \\
SM of $M$. anisopliae M16 & $48.62 \mathrm{~b}$ \\
SM of $L$. lecanii L16 & $56.62 \mathrm{~b}$ \\
\hline
\end{tabular}

Numbers followed by different letters show a significant difference in the HSD test with an error level of 5\%. 
enzymes, such as chitinase. Chitinase had a mechanism to degrade chitin, which is a constituent of the fungal conidia walls of F. oxysporum f.sp. capsici (Kumar et al., 2018). The enzyme content for each entomopathogenic fungus was different. This was shown by the inhibition of the enzyme on the growth of $F$. oxysporum f.sp. capsici versus control. B. bassiana fungus produced secondary metabolites, as did the other entomopathogenic fungi that were tested (Keswani et al., 2013).

Morphological observations on the hyphal structure of $F$. oxysporum f.sp. capsici against fungal entomopathogenic secondary metabolites showed structural change. The swelling of the pathogenic fungal hyphae was thought to be due to lysis activity due to cell wall lysis enzymes, which contained in the secondary metabolites of entomopathogenic fungi (Molnar et al., 2010). Petrisor \& Stoian (2017) stated that secondary metabolite compounds that enter fungal cells would cause mycolysis. Mycolysis was the loss of protoplasm in the cell wall structure so that the enzyme does not dissolve in the fungal cell wall. Mycolysis could cause thickening, shortening, and lysis of the walls so that the growth of hyphae becomes abnormal.

\section{Effect of Secondary Metabolites of Four Entomopathogenic Fungi on Pathosystem Components. The incubation period of $F$. oxysporum}

f.sp. capsici (Table 2) showed that the treatment of entomopathogenic fungi secondary metabolites had a significant effect when compared to the control. The entomopathogenic fungal secondary metabolites could all prolong the incubation period. This was presumably because the control plants were not treated with entomopathogenic fungal secondary metabolites, so the plants did not had resistance to infection of $F$. oxysporum f.sp. capsici. This was in accordance with the opinion of Leclerc et al. (2014) stated that the shorter incubation period indicates a high degree of host pathogen suitability.

The application of secondary metabolites from B. bassiana B10, B. bassiana B16, M. anisopliae M16, and $L$. lecanii $\mathrm{L} 16$ was able to prolong the incubation period
(Table 2). It was assumed that the application of entomopathogenic fungi secondary metabolites could inhibit the growth of $F$. oxysporum f.sp. capsici due to the presence of annoying toxic compounds. As reported, the entomopathogenic fungi produce secondary metabolites, which cause the development of pathogens to be inhibited, thus affecting the incubation period (Molnar et al., 2010).

In line with the incubation period, four secondary metabolites of entomopathogenic fungi emphasized disease intensity. Based on Table 2, the entomopathogenic fungal secondary metabolites was significantly different when compared to controls. Even the inter-treatment of entomopathogenic fungal secondary metabolites had the same effect, and was able to suppress the intensity of the disease (Figure 1). It is suspected that the active compound present in the secondary metabolites of entomopathogenic fungi are able to inhibit the infection of the pathogen F. oxysporum f.sp. capsici.

This was in accordance with the opinion of Błaszczyk et al. (2021), that L. lecanii produces toxic secondary metabolites, namely bassionolidae and dipicolinic acid. L. lecanii and other enthomopathogenic fungi secretes a small amount of $\alpha-1,3$ gluconase and protease enzymes which function to degrade cell walls (Mondal et al., 2016). The ability of enthomopathogenic fungi to control plant diseases was proven by Rustiguel et al. (2012). Kim et al. (2013) and Litwin et al. (2020) that entomopathogenic fungi secondary metabolites acted as pesticides by extracelular enzymes.

In addition, the application of entomopathogenic fungal secondary metabolites was able to increase plant defence against $F$. oxysporum f.sp. capsici. This was supported by a qualitative analysis of the plant phenolic compounds content (Table 4). Phenolic compounds were parameters of biochemical impacted plant resistance, which can overcome pathogen attack. The increase in plant phenolic content was due to the presence of foreign compounds that enter the plant tissue, in this case the secondary metabolites of entomopathogenic fungi that were applied (Litwin et al., 2020). Plants that were

Table 2. Incubation period and intensity of fusarium wilt disease in secondary metabolites treatment of four entomopathogenic fungi

\begin{tabular}{lcc}
\hline Treatments & Incubation period (dai) & Disease intensity (\%) \\
\hline Control & $6.6 \mathrm{a}$ & $21.33 \mathrm{a}$ \\
SM of $B$. bassiana B10 & $22.8 \mathrm{~b}$ & $0.01 \mathrm{~b}$ \\
SM of $B$. bassiana B16 & $24.8 \mathrm{~b}$ & $0.01 \mathrm{~b}$ \\
SM of $M$. anisopliae M16 & $18.8 \mathrm{~b}$ & $0.01 \mathrm{~b}$ \\
SM of $L$. lecanii L16 & $21.0 \mathrm{~b}$ & $0.01 \mathrm{~b}$ \\
\hline
\end{tabular}

Numbers followed by different letters in the same column show a significant difference in the HSD test with an error level of $5 \%$. 
systemically resistant and contain compounds in the secondary metabolites of entomopathogenic fungi would be able to overcome the attack of pathogenic fungi, so that the disease intensity decreases (Sharma \& Gupta, 2020). The active ingredients in the entomopathogenic fungal secondary metabolites enter the plant tissue through root absorption. Furthermore, secondary metabolite compounds were transported throughout the plant tissue (Barra-Bucarei et al., 2020).

Effect of Secondary Metabolites of Four Entomopathogenic Fungi on Growth Components. The treatment of each secondary metabolite of B. bassiana B10, B. bassiana B16, M. anisopliae M16, and L. lecanii L16 showed significant differences in plant height or able to increase plant height (Table 3). In the control, the lowest plant height was thought to be disturbed by nutrient absorption from the soil, because the roots of the plants were broken due to $F$. oxysporum f.sp. capsici infection. According to Bani et al. (2018), Fusarium sp. infection was spread from the root to the entire plant through the xylem vessels, thus interfering with the process of water transport and absorption of nutrients in plants and eventually the plant withers. When attacking chili plants, Fusarium sp. cause the roots to form a pile or colony at the base of the plant stems, the fungus would take the nutrients the plant needs, as a result, the food supply to the roots that should be distributed to plant tissue was reduced (Farahani-Kofoet et al., 2020).
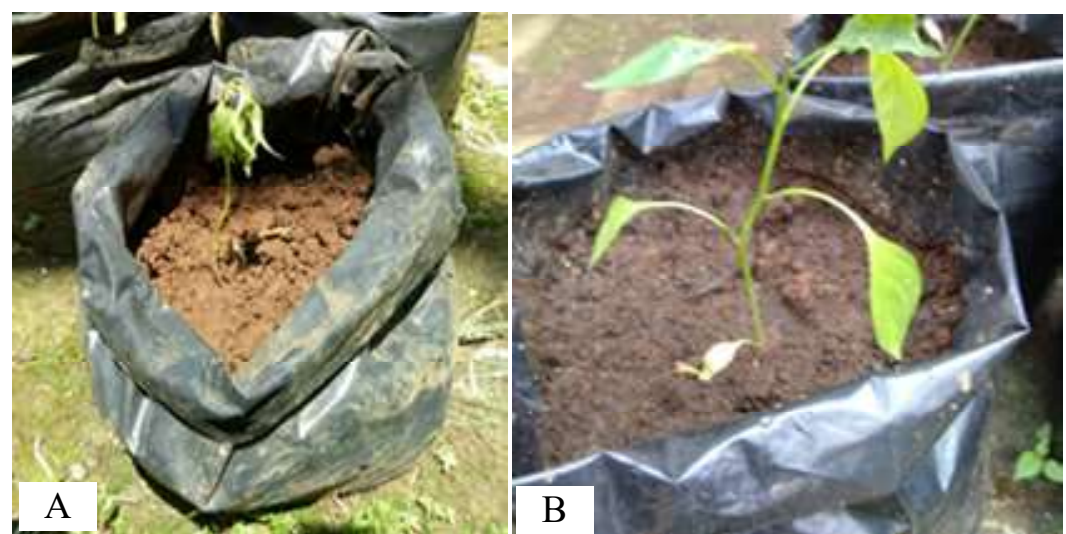

Figure 1. Application of entomopathogenic fungal secondary metabolites on fusarium wilt of chili seedlings. (A) Control;

(B) Treated chili seedling.

Table 3. Differences in average plant height and root length of chili crops in the treatment of secondary metabolites of four entomopathogenic fungi

\begin{tabular}{lcc}
\hline Treatments & Crop height $(\mathrm{cm})$ & Root length $(\mathrm{cm})$ \\
\hline Control & $22.60 \mathrm{a}$ & $5.2 \mathrm{a}$ \\
SM of $B$. bassiana B10 & $28.86 \mathrm{~b}$ & $7.0 \mathrm{~b}$ \\
SM of $B$. bassiana B16 & $28.66 \mathrm{~b}$ & $7.8 \mathrm{~b}$ \\
SM of $M$. anisopliae M16 & $26.66 \mathrm{~b}$ & $6.7 \mathrm{~b}$ \\
SM of $L$. lecanii L16 & $27.86 \mathrm{~b}$ & $7.1 \mathrm{~b}$ \\
\hline
\end{tabular}

Numbers followed by different letters in the same column show a significant difference in the HSD test with an error level of $5 \%$.

Table 4. Content of phenolic compounds qualitatively found in chili plants due to the treatment of secondary metabolites of four entomopathogenic fungi

\begin{tabular}{lccc}
\hline Treatments & Tannins & Saponins & Hydroquinon \\
\hline Control & + & + & + \\
SM of $B$. bassiana B10 & ++ & ++ & ++ \\
SM of $B$. bassiana B16 & ++ & ++ & ++ \\
SM of M. anisopliae M16 & ++ & ++ & ++ \\
SM of L. lecanii L16 & ++ & $+1+$ & ++ \\
\hline
\end{tabular}

$+=\mathrm{a}$ little; $++=$ quite a lot; $+++=\mathrm{a}$ lot. 
Based on Table 3, each secondary metabolites of B. bassiana B10, B. bassiana B16, M. anisopliae M16, and $L$. lecanii $\mathrm{L} 16$ was able to affect root length or increase root length. Farahani-Kofoet et al. (2020) stated that the roots of plants infected by $F$. oxysporum would rot and cause the plants to collapse easily, so they are easily uprooted. Bani et al. (2018) and de Lamo \& Takken (2020) stated that $F$. oxysporum could attack vessel tissue, thereby inducing root rot.

In addition, the application of each of the four entomopathogenic fungal secondary metabolites was able to extend plant roots. Lopez \& Sword (2015) reported that B. bassiana promotes plant growth of cotton (Gossypium hirsutum). B. bassiana inoculation had a positive effect on plant growth parameters including root length of common beans (Phaeseolus vulgaris) (Afandhi et al., 2019). Foliar inoculation of plants with the tested strains of $B$. bassiana and $M$. anisopliae increased plant height, leaf pair number, fresh shoot and root weights; however the increase was not always consistent across sampling dates (Jaber \& Enkerli, 2017). The secondary metabolites producing enthomopathogenic fungi had been also reported as a plant tissue colonizer, plant growth enhancer, or as a naturally occurring endophyte (Ríos-Moreno et al., 2016).

\section{Effect of Secondary Metabolites of Four Entomopathogenic Fungi on Phenolic Compound} Content. The qualitative tested tissue analysis was presented in Table 4. The results of the tannin compound test showed that the application of each secondary metabolite of B. bassiana B10, B. bassiana B16, $M$. anisopliae M16, and $L$. lecanii L16 produced more tannin compounds when compared to the control. It wes suspected that the treatment of four secondary metabolites of entomopathogenic fungi could increase tannin compounds in chili plants. The parameter of the amount of tannin content in plants could be seen in the presence of turquoise or blackish green.

This was in accordance with the opinion of Auwal et al. (2014), that a positive result on tannin testing was that the plant extract would be blackish blue due to the $\mathrm{FeCl}_{3}$ reagent. The content of tannin compounds in the treatment of four secondary metabolites of entomopathogenic fungi was shown to have almost the same tannin content, and had good resistance to increasing the potency of tannin compounds compared to control.

Saponin test results showed that the application of each secondary metabolite $B$. bassiana $\mathrm{B} 10, B$. bassiana B16, M. anisopliae M16, and L. lecanii L16 increased saponin content when compared to control (Table 4). This was in accordance with Juric et al. (2020), that the increase in phenol content due to the addition of antagonistic fungal metabolites. Plant content of secondary plant metabolites was affected by genetic, environmental, and agronomic factors (Neugart et al., 2018). Because the antagonistic fungal supernatant was absorbed by plants, substances that could be responsible for affected resistance give rise.

The results of the hydroquinone test on the treatment of four secondary metabolites of entomopathogenic fungi were more than the control (Table 4). Hydroquinone compounds were marked with a brick red color which could be seen in the chili leaf extract. Rahmania et al. (2018) confirmed that, the brick red color formed indicates the presence of hydroquinone. The presence of hydroquinone compounds in a plant would increase plant resistance to pathogen attack.

The increase in the content of these phenolic compounds (tannins, saponins, and hydroquinones) supported the observation of a longer incubation period and low disease intensity, even without disease symptoms (Table 2). Phenolic compounds were components of plant defense from within, which could be systemically induced through the application of entomopathogenic fungal secondary metabolites. Secondary metabolites that wre absorbed by plants would wake up the signal for phenol compounds to increase and function to overcome existing pathogens (Dangl \& Jones, 2001).

\section{CONCLUSION}

The secondary metabolites of $B$. bassiana B10, B. bassiana B16, M. anisopliae M16, and L. lecanii L16 were able to inhibit growth of $F$. oxysporum $\mathrm{f}$. sp. capsici, extend incubation periods, suppress disease intensity, increase plant height, and increase root length. It also increase the content of tannins, saponins, and hydroquinone compounds qualitatively compared to controls. The secondary metabolites of enthomopathogenic fungi could be used as organic control for soilborne pathogenic fungi.

\section{ACKNOWLEDGMENTS}

Thanks go to Prof. Ir. Totok Agung Dwi H., M.P., $\mathrm{Ph}$.D. for reading this manuscript.

\section{REFERENCES}

Abdel-Monaim MF \& Ismail ME. 2010. The use of antioxidants to control roor rot and wilt diseases of pepper. Not Sci. Biol. 2(2): 46-55.

Afandhi A, Widjayanti T, Emi AAL, Tarno H, Afiyanti M, \& Handoko RNS. 2019. Endophytic fungi 
Beauveria bassiana Balsamo accelerates growth of common bean (Phaeseolus vulgaris L.). Chem. Biol. Technol. Agric. 6: 11.

Altinok HH, Altinok MA, \& Koca AS. 2019. Modes of action of entomopathogenic fungi. Curr. Trends Nat. Sci. 8(16): 117-124.

Auwal MS, Saka S, Mairiga IA, Sanda KA, Shuaibu A, \& Ibrahim A. 2014. Preliminary phytochemical and elemental analysis of aqueous and fractionated pod extracts of Acacia nilotica (Thorn mimosa). Vet. Res. Forum. 5(2): 95-100.

Baenas N, Belovic M, Ilic N, Moreno DA, \& GarcíaViguera C. 2018. Industrial use of pepper (Capsicum annum L.) derived products: technological benefits and biological advantages. Food Chem. 274: 872885.

Bani M, Pérez-De-Luque A, Rubiales D, \& Rispail N. 2018. Physical and chemical barriers in root tissues contribute to quantitative resistance to Fusarium oxysporum f.sp. pisi in pea. Front Plant Sci. 9: 199.

Barra-Bucarei L, Iglesias AF, González MG, Aguayo GS, Carrasco-Fernández J, Castro JF, \& Campos JO. 2020. Antifungal activity of Beauveria bassiana endophyte against Botrytis cinerea in two Solanaceae crops. Microorganisms. 8(1): 65.

Bashir MR, Atiq M, Sajid M, Mohsan M, Abbas W, Alam MW, \& Bashair M. 2018. Antifungal exploitation of fungicides against Fusarium oxysporum f.sp. capsici causing Fusarium wilt of chilli pepper in Pakistan. Environ. Sci. Pollut. Res. 25(2): 67976801.

Bekker TF, Kaiser C, Merwe Rvd, \& Labuschagne N. 2006. In-vitro inhibition of mycelial growth of several phytopathogenic fungi by soluble potassium silicate. S. Afr. J. Plant Soil. 23(3): 169-172.

Bele AA, Jadhav VM, \& Kadam VJ. 2010. Potential of tannnins: a review. Asian J. Plant Sci. 9(4): 209214.

Besset-Manzoni Y, Joly P, Brutel A, Gerin F, Soudière O, Langin T, \& Prigent-Combaret C. 2019. Does in vitro selection of biocontrol agents guarantee success in planta? A study case of wheat protection against Fusarium seedling blight by soil bacteria. PLoSOne. 14(12): e0225655.

Błaszczyk L, WaskiewiczA, Gromadzka K, Mikołajczak K, \& Chełkowski J. 2021. Sarocladium and
Lecanicillium associated with maize seeds and their potential to form selected secondary metabolites. Biomolecules. 11(1): 98.

Corrêa B, da Silveira Duarte V, Silva DM, Mascarin GM, \& Júnior ID. 2020. Comparative analysis of blastospore production and virulence of Beauveria bassiana and Cordyceps fumosorosea against soybean pests. BioControl. 65: 323-337.

Dangl JL \& Jones JDG. 2001. Plant pathogens and integrated defence responses to infection. Nature. 411: 826-833.

de Laguna IHB, Marante FJT, \& Mioso R. 2015. Enzymes and bioproducts produced by the ascomycete fungus Paecilomyces variotii. J. Appl. Microbiol. 119(6): 1455-1466.

de Lamo FJ \& Takken FLW. 2020. Biocontrol by Fusarium oxysporum using endophyte-mediated resistance. Front Plant Sci. 11: 37.

Farahani-Kofoet RD, Witzel K, Graefe J, Grosch R, \& Zrenner R. 2020. Species-specific impact of Fusarium infection on the root and shoot characteristics of Asparagus. Pathogens. 9(6): 509.

Fernandes EG, Valério HM, Feltrin T, \& der Sand STV. 2012. Variability in the production of extracellular enzymes by entomopathogenic fungi grown on different substrates. Braz. J. Microbiol. 43(2): 827833.

Fitriana Y, Suharjo R, Swibawa IG, Purnomo, Lestari P, \& Merdiana E. 2018. Influence of culture medium on the sporulation and viability of Aspergillus spp. and Talaromyces spp. entomopathogenic fungi. J. HPT Tropika. 18(1): 12-22.

Gabrekiristos E \& Demiyo T. 2020. Hot pepper Fusarium wilt (Fusarium oxysporum f.sp. capsici): Epidemics, characteristic features and management options. J. Agric. Sci. 12(10): 347-360.

Gordon TR. 2017. Fusarium oxysporum and the Fusarium wilt syndrome. Annu. Rev. Phytopathol. 55(1):2339.

Gull I, Javed A, Aslam MS, Mushtaq R, \& Athar MA. 2016. Use of Moringa oleifera flower pod extract as natural preservative and development of SCAR marker for Its DNA based identification. BioMed Res. Int. 2016(2): 1-12.

Gustianingtyas M, Herlinda S, Suwandi, Suparman, Hamidson H, Hasbi, Setiawan A, Verawaty M, Elfita, \& Arsi. 2020. Toxicity of entomopathogenic fungal 
culture filtrate of lowland and highland soil of South Sumatra (Indonesia) against Spodoptera litura larvae. Biodiversitas. 21(5): 1839-1849.

Hsia ICC, Islam TMd, Ibrahim Y, How TY, \& Omar D. 2014. Evaluation of conidial viability of entomopathogenic fungi as influenced by temperature and additive. Int. J. Agric. Biol. 16(1): 146-152.

Jaber LR \& Enkerli J. 2017. Fungal entomopathogens as endophytes: can they promote plant growth? Biocontrol Sci. Technol. 27(1): 28-41.

Jaber LR \& Ownley BH. 2018. Can we use entomopathogenic fungi as endophytes for dual biological control of insect pests and plant pathogens? Biol. Control. 116: 36-45.

Juric S, Stracenski KS, Król-Kiliñska Z, Žutic I, Uher SF, Đermic E, Topolovec-Pintaric S, \& Vincekovic M. 2020. The enhancement of plant secondary metabolites content in Lactuca sativa L. by encapsulated bioactive agents. Sci. Rep 10(1): 3737.

Kalman B, Abraham D, Graph S, Perl-Treves R, Harel $\mathrm{YM}$, \& Degani O. 2020. Isolation and identification of Fusarium spp., the causal agents of onion (Allium сера) basal rot in Northeastern Israel. Biology. 9(4): 69.

Keswani C, Singh SP, \& Singh HB. 2013. Beauveria bassiana: status, mode of action, applications and safety issues. Biotech Today. 3(1): 16-19.

Kim JJ, Jeong G, Han JH, \& Lee S. 2013. Biological control of aphid using fungal culture and culture filtrates of Beauveria bassiana. Mycobiology. 41(4): 221224.

Köhl J, Kolnaar R, \& Ravensberg WJ. 2019. Mode of action of microbial biological control agents against plant diseases: relevance beyond efficacy. Front. Plant Sci. 10: 845.

Kumar M, Brar A, Yadav M, Chawade A, Vivekanand V, \& Pareek N. 2018. Chitinases-potential candidates for enhanced plant resistance towards fungal pathogens. Agriculture. 8(7): 88.

Leclerc M, Doré T, Gilligan CA, Lucas P, \& Filipe JAN. 2014. Estimating the delay between host infection and disease (incubation period) and assessing its significance to the epidemiology of plant diseases. PLoS One. 9(1): e86568.
Litwin A, Nowak M, \& Rózalska S. 2020. Entomopathogenic fungi: unconventional applications. Rev. Environ. Sci. Biotechnol. 19: 23-42.

Lopez DC \& Sword GA. 2015. The endophytic fungal entomopathogens Beauveria bassiana and Purpureocillium lilacinum enhance the growth of cultivated cotton (Gossypium hirsutum) and negatively affect survival of the cotton bollworm (Helicoverpa zea). Biol. Control. 89: 53-60.

Molnar I, Gibson DM, \& Krasnoff SB. 2010. Secondary metabolites from entomopathogenic Hypocrealean fungi. Nat. Prod. Rep. 27(9): 1241-1275.

Mondal S, Baksi S, Koris A, \& Vatai G. 2016. Journey of enzymes in entomopathogenic fungi. Pac. Sci. Rev.. 18(2): 85-99.

Mora MAE, Castilho AMC, \& Fraga ME. 2017. Classification and infection mechanism of entomopathogenic fungi. Arq. Inst. Biol. 84: e0552015.

Neugart S, Baldermann S, Hanschen FS, Klopsch R, Wiesner-Reinhold M, \& Schreiner M. 2018. The intrinsic quality of brassicaceous vegetables: how secondary plant metabolites are affected by genetic, environmental, and agronomic factors. Sci. Hortic. 233: $460-478$.

Olatunji TL \& Afolayan AJ. 2018. The suitability of chili pepper (Capsicum annuum L.) for alleviating human micronutrient dietary deficiencies: a review. Food Sci. Nutr. 6(8): 2239-2251.

Ownley BH, Gwinn KD, \& Vega FE. 2010. Endophytic fungal entomopathogens with activity against plant pathogens: ecology and evolution. BioControl. 55: $113-128$.

Petrisor C \& Stoian G. 2017. The role of hydrolytic enzymes produced by entomopathogenic fungi in pathogenesis of insects. Rom. J. Plant Prot. 10: 66-72.

Rahmania N, Herpandi, \& Rozirwan. 2018. Phytochemical test of mangrove Avicennia alba, Rhizophora apiculata and Sonneratia alba from Musi River Estuary, South Sumatera. BIOVALENTIA: Biological Research Journal. 4(2): 1-8.

Ribeiro BD, Barreto DW, \& Coelho MAZ. 2013. Application of foam column as green technology for concentration of saponins from sisal (Agave sisalana) and juá (Ziziphus joazeiro). Braz. J. Chem. Eng. 30(4): 701-709. 
Ríos-Moreno A, Garrido-Jurado I, Resquín-Romero G, Arroyo-Manzanares N, Arce L, \& QuesadaMoraga E. 2016. Destruxin a production by Metarhizium brunneum strains during transient endophytic colonisation of Solanum tuberosum. Biocontrol Sci. Technol. 26(11): 1574-1585.

Roshandel S, Askary H, Hassanlouei RT, \& Allahyari H. 2016. The effect of natural substrates on the sporulation and viability of conidia and blastospores of Metarhizium anisopliae. BCPP. 4(1): 94-104.

Rustiguel CB, Joao AJ, \& Guimarães LHS. 2012. Optimization of the chitinase production by different Metarhizium anisopliae strains under solid-state fermentation with silkworm chrysalis as substrate using CCRD. Adv. Microbiol. 2: 268-276.

Sharma S \& Gupta N. 2020. Defense signaling in plants against micro-creatures: do or die. Indian Phytopathol. 73: 605-613.

Soesanto L, Kustam, \& Mugiastuti E. 2019. Application of Bio P60 and Bio T10 in combination against Phytophthora wilt of papaya. Biosaintifika: Journal of Biology \& Biology Education. 11(3): 339-344.
Velarde-Félix S, Garzón-Tiznado JA, Hernández-Verdugo S, López-Orona CA, \& Retes-Manjarrez JE. 2018. Occurrence of Fusarium oxysporum causing wilt on pepper in Mexico. Can. J. Plant Pathol. 40(2): 238-247.

Velivelli S, de Vos P, Kromann P, Declerck S, \& Prestwich BD. 2014. Biological control agents: from field to market, problems, and challenges. Trends Biotechnol. 32(10): 493-496.

Vidal NP, Adigun OA, Pham TH, Mumtaz A, Manful C, Callahan G, Stewart P, Keough D, \& Thomas RH. 2018. The effects of cold saponification on the unsaponified fatty acid composition and sensory perception of commercial natural herbal soaps. Molecules. 23(9): 2356.

Živkovic S, Stojanovic S, Ivanovic Z, Gavrilovic V, Popovic T, \& Balaž JS. 2010. Screening of antagonistic activity of microorganisms against Colletotrichum acutatum and Colletotrichum gloeosporioides. Arch. Biol. Sci. 62(3): 611-623. 